\title{
Epigenetic alterations following early postnatal stress: a review on novel aetiological mechanisms of common psychiatric disorders
}

Magdalene C. Jawahar ${ }^{1}$, Chris Murgatroyd ${ }^{2}$, Emma L. Harrison ${ }^{1,3}$ and Bernhard T. Baune ${ }^{1 *}$

\begin{abstract}
Stressor exposure during early life has the potential to increase an individual's susceptibility to a number of neuropsychiatric conditions such as mood and anxiety disorders and schizophrenia in adulthood. This occurs in part due to the dysfunctional stress axis that persists following early adversity impairing stress responsivity across life. The mechanisms underlying the prolonged nature of this vulnerability remain to be established. Alterations in the epigenetic signature of genes involved in stress responsivity may represent one of the neurobiological mechanisms. The overall aim of this review is to provide current evidence demonstrating changes in the epigenetic signature of candidate gene(s) in response to early environmental adversity. More specifically, this review analyses the epigenetic signatures of postnatal adversity such as childhood abuse or maltreatment and later-life psychopathology in human and animal models of early life stress. The results of this review shows that focus to date has been on genes involved in the regulation of hypothalamic-pituitary-adrenal (HPA) axis and its correlation to subsequent neurobiology, for example, the role of glucocorticoid receptor gene. However, epigenetic changes in other candidate genes such as brain-derived neurotrophic factor (BDNF) and serotonin transporter are also implicated in early life stress (ELS) and susceptibility to adult psychiatric disorders. DNA methylation is the predominantly studied epigenetic mark followed by histone modifications specifically acetylation and methylation. Further, these epigenetic changes are cell/tissue-specific in regulating expression of genes, providing potential biomarkers for understanding the trajectory of early stress-induced susceptibility to adult psychiatric disorders.
\end{abstract}

Keywords: Early life stress, Maternal separation, Epigenetics, DNA methylation, Stress-responsive genes, Histone acetylation, Psychopathology

\section{Background}

Early life stress (ELS) encompasses childhood abuse, neglect, poverty and parental illness, alongside a multitude of other stressors. Some forms of ELS affect 30$40 \%$ of the Western population and have been implicated in approximately half of all childhood and a third of adulthood psychiatric disorders [1, 2]. Exposure to ELS results in enhanced susceptibility to neuropsychiatric disorders such as major depressive disorder, generalised anxiety disorder, schizophrenia and autism

\footnotetext{
* Correspondence: Bernhard.Baune@Adelaide.edu.au

'Discipline of Psychiatry, School of Medicine, University of Adelaide, Adelaide, SA 5005, Australia

Full list of author information is available at the end of the article
}

spectrum disorders $[1,3,4]$. Chronic health conditions such as obesity, type two diabetes mellitus, respiratory disorders and cardiovascular diseases are also increased in individuals with a history of ELS $[5,6]$.

The impact of early adversity on the susceptibility to psychiatric disorders in later life is influenced by a number of factors. Environmental factors include nature of stressors [7], time of exposure in development $[8,9]$ and severity and cumulative exposure effects [10-12]. Biological factors include gender, age of assessment [13] and predisposing genetic polymorphisms in genes associated with mood regulation, stress response and inflammatory processes. These include genes such as serotonin transporter $(5-H T T)$, brain-derived neurotrophic factor 
$(B D N F)$ and FK506 binding protein (FKBP5) [14-16]. A dysfunctional hypothalamic-pituitary-adrenal (HPA) stress axis and impaired immune responses such as increased cytokines have also been implicated in the increased vulnerability to ELS $[17,18]$. In spite of the increasing knowledge, the molecular mechanisms underlying ELS-mediated long-term vulnerability to later-life stressors are unclear.

Gene-environment interactions, such as those occurring when exposed to ELS, often encompass epigenetic changes. Epigenetics processes occur at the level above the genome, which includes DNA methylation, posttranslational histone modifications and gene regulation by micro-RNA (miRNA). Collectively, these epigenetic changes can stably mark the genome in response to environment, potentially altering gene expression across lifespan [19, 20] and across generations [21]. As such, epigenetic alterations may represent one of the key mechanisms underlying the long-lasting nature of ELSinduced changes in neurobiology, behaviour and disease susceptibility [22, 23].

We first present a brief overview of the stress response pathways followed by a detailed review of evidence demonstrating epigenetic alterations following ELS in animal models and humans. Changes in the epigenetic signature of candidate genes and alterations in genome-wide methylation will be reported. Finally, we aim to understand how these changes mediate long-term effects such as their role in risk to developing psychiatric disorders in adulthood.

\section{The central role of hypothalamus-pituitary-adrenal system}

Adversities during early postnatal life are able to shape the experience-dependent maturation of stressregulating pathways, such as the HPA system. This can lead to persistent alterations in stress responsivity during adulthood-a phenomenon often referred to as "early-life programming". Tight regulation of the HPA axis is therefore core to the long-term control of systems governing stress responsivity. The HPA axis involves the release, following a stressor, of the neuropeptide corticotrophin-releasing hormone (CRH) and arginine vasopressin (AVP) from the paraventricular nucleus (PVN) of the hypothalamus. These bind to their specific receptors (the CRHR1 and V1b receptors) in the anterior pituitary that stimulate the release of adrenocorticotrophic hormone (ACTH) which stimulates the adrenal cortex to release glucocorticoid (GC) hormones, cortisol in human and corticosterone in rodents. These GCs in turn mobilise glucose from energy stores and increase cardiovascular tone, among further widespread effects. Feedback loops, primarily mediated through glucocorticoid receptors (GRs) in the PVN and pituitary, regulate responsiveness of the HPA axis ensuring a return to a homeostatic balance when it is no longer challenged (Fig. 1).

A loss of this negative feedback control, particularly following periods of chronic stress, may influence the development of affective disorders. Indeed, dysregulated HPA activity is one of the most commonly observed neuroendocrine symptoms in major depressive disorder (for review see [24]). Childhood stress has also been shown to be a strong predictor of impaired inhibitory feedback regulation of the HPA axis with evidence linking to a role of CRH and/or AVP systems. For example, postmortem brain tissue of depressed individuals revealed elevated CRH and AVP in the hypothalamus [25, 26]. Studies in rodent models further support the concept that exposure to a chronic stressor can lead to long-term changes in HPA regulation and behaviour stemming from changes in neuropeptide regulation (for review see [27]).

\section{The role of candidate genes outside of the HPA axis}

Candidate genes such as the serotonin transporter SLC6A4 and BDNF have been highly implicated in stress response and in increased risk for psychiatric disorders [28-32]. BDNF is the most prevalent growth factor in the central nervous system (CNS) and important in neuronal development and plasticity [33]. Serotonin transporter is involved in the reuptake of serotonin from the brain synapses regulating serotonin signalling and is the target for many antidepressants [34]. SLC6A4 or 5-HTT carries a genetic polymorphism in the promoter region resulting in a short "s" and a long "l" allele version of the promoter [35]. The "s" allele is associated with poor transcriptional efficiency of SLC6A4 compared to "l" allele [35]. The BDNF gene carries a Val66Met polymorphism which impacts an activity-dependent expression of BDNF and the intracellular trafficking [36]. In combination with exposure to ELS events, both SLC6A4 and BDNF polymorphisms have been attributed to increased risk for depression in later life [28, 30, 37]. Further, steroid hormone estrogen and its receptors have been shown to influence brain function and psychiatric disorders (for review see [38]). Animal models analysing maternal care in rats identified estrogen receptor $\alpha$ expression was altered with the type of maternal care, and this was passed across generations [39]. A detailed analysis of the role of these and other candidate genes implicated in ELS and later-life psychopathology is reviewed in the following sections. 


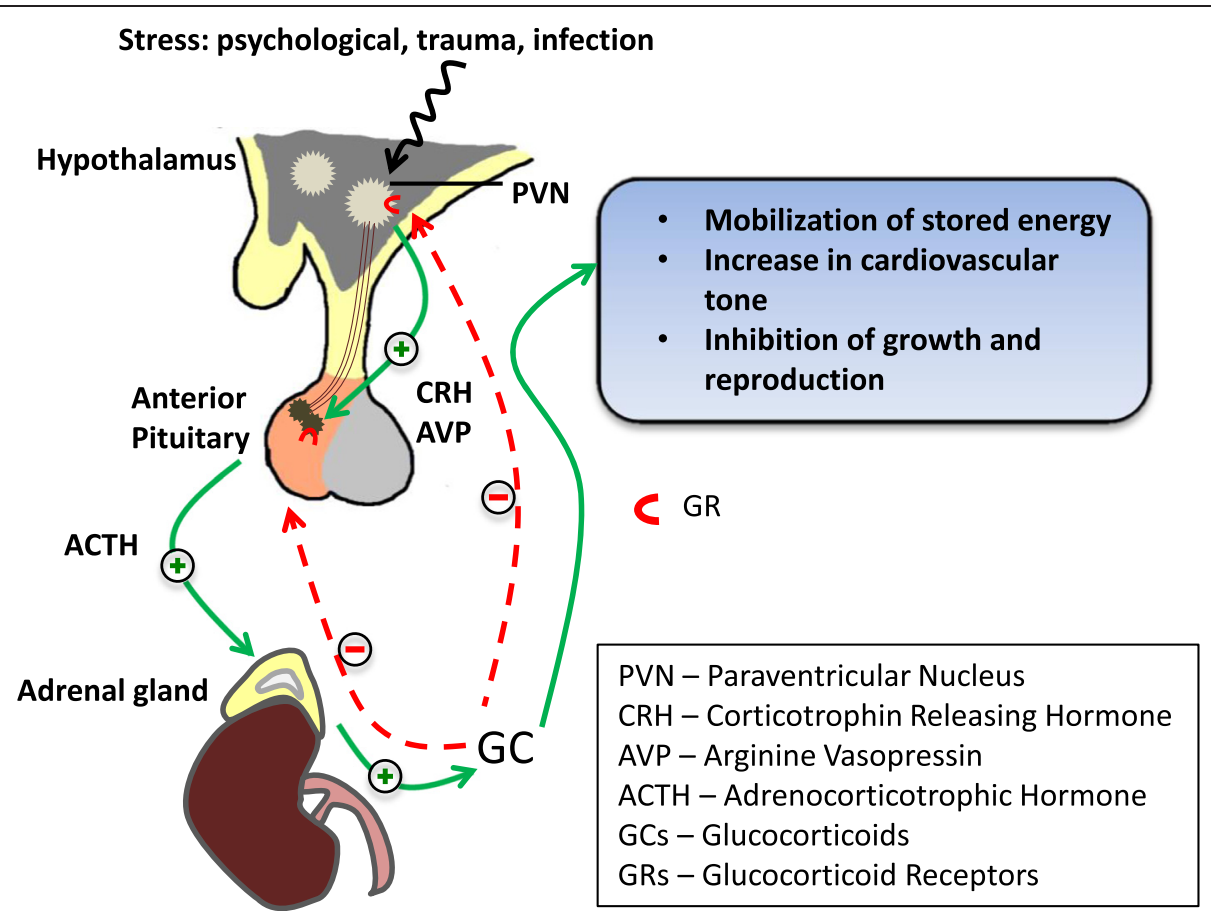

Fig. 1 The hypothalamic-pituitary-adrenal (HPA) axis and its response to stress stimuli: the signalling events (green, solid lines) in the HPA axis in response to stress stimuli and how glucocorticoids (GCs) produced by the adrenal gland can have a negative feedback role in maintaining GC levels in the blood. The negative feedback in the hypothalamus and pituitary (red, dotted lines) are both mostly regulated by glucocorticoid receptors (GRs), and dysfunctional negative feedback system is often seen associated with chronic exposure to stress stimuli

\section{ELS-induced epigenetic modifications in animal models}

A variety of animal models are currently being used to model ELS paralleling childhood adversity in humans (Table 1). Each paradigm facilitates investigation into ELS-induced alterations in the developing animal and centres on the importance of mother for normal nervous, immune and endocrine system development [4042]. A majority of the literature on animal models discussed in this review will therefore be on variations in maternal care.

\section{ELS-induced epigenetic changes in HPA axis genes}

Given the central role of the HPA axis in stress responsivity and adaptation to ELS, the genes involved in regulating this system have been of focus in ELS-induced epigenetic studies (see Table 2 for summary of studies).

\section{Glucocorticoid receptor gene}

Pioneering studies on epigenetic alterations in GR promoter in response to variations in maternal care were first shown by Weaver and colleagues [20]. They re-

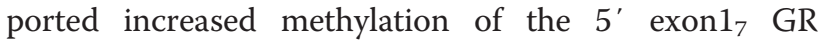

Table 1 Commonly used models of early adversity in animal studies

\begin{tabular}{|c|c|c|c|}
\hline Paradigm & Description & Rationale & References \\
\hline Handling & $\begin{array}{l}\text { Daily separation of pups as a litter from mother for } 15 \text { min } \\
\text { from PND1-14 (up to PND21) }\end{array}$ & $\begin{array}{l}\text { Allows comparison of mild vs severe stress-induced effects } \\
\text { during the early postnatal period }\end{array}$ & {$[94]$} \\
\hline $\begin{array}{l}\text { Early } \\
\text { weaning }\end{array}$ & Weaning of pups between PND14 and PND21 & $\begin{array}{l}\text { Enables assessment of prolonged stress after the early } \\
\text { postnatal period }\end{array}$ & {$[42,95]$} \\
\hline $\begin{array}{l}\text { Maternal } \\
\text { separation }\end{array}$ & $\begin{array}{l}\text { Daily separation of pups individually or as a litter from mother } \\
\text { for } 3 \text { h (up to } 6 \text { h) from PND1-14 (up to PND21) }\end{array}$ & $\begin{array}{l}\text { Ethnologically relevant as it models repeated episodes of } \\
\text { mild stress rather than } 1 \text { episode of severe stress during } \\
\text { the early postnatal period }\end{array}$ & {$[96]$} \\
\hline $\begin{array}{l}\text { Maternal } \\
\text { deprivation }\end{array}$ & $\begin{array}{l}\text { Single episode of separation of pups as a litter from mother } \\
\text { for } 24 \text { h, usually on PND3 or } 9\end{array}$ & $\begin{array}{l}\text { Allows determination of stress-induced effects at specific } \\
\text { developmental time windows within the early postnatal } \\
\text { period }\end{array}$ & $\begin{array}{l}{[41,47,} \\
95]\end{array}$ \\
\hline $\begin{array}{l}\text { Low vs } \\
\text { high LG- } \\
\text { ABN }\end{array}$ & $\begin{array}{l}\text { Pups raised by biological mothers who are characterised as } \\
\text { either low or high care dams on the basis of the level of } \\
\text { licking grooming arched-back nursing they perform }\end{array}$ & $\begin{array}{l}\text { Enables comparison of the effects of variations in maternal } \\
\text { care on development rather than stress exposure }\end{array}$ & {$[39,97]$} \\
\hline
\end{tabular}

$h$ hour, $L G-A B N$ licking grooming arched-back nursing, PND postnatal day 
Table 2 Early stress-induced epigenetic changes in stress-regulatory genes in animal studies

\begin{tabular}{|c|c|c|c|c|}
\hline $\begin{array}{l}\text { Candidate } \\
\text { gene }\end{array}$ & Objective & Model/tissue type & $\begin{array}{l}\text { Early stress/ } \\
\text { assessment age }\end{array}$ & $\begin{array}{l}\text { Epigenetic and expression } \\
\text { changes }\end{array}$ \\
\hline $\begin{array}{l}\text { GR } \\
\text { promoter }\end{array}$ & $\begin{array}{l}\text { Determine the effect of } \\
\text { maternal care on exon } \\
1_{7} \mathrm{GR} \text { promoter } \\
\text { methylation and } \\
\text { histone H3K9 } \\
\text { acetylation }\end{array}$ & Long-Evans rats & $\begin{array}{l}\text { Maternal care } \\
\text { variations: high vs } \\
\text { low LG- } \\
\text { ABNAssessed: PND6, } \\
21 \text { and } 90\end{array}$ & $\begin{array}{l}\downarrow \text { methylation } 5^{\prime} \mathrm{CpG} \text { of } \\
\text { NGFI-A response element } \\
\text { in high vs low } L G-A B N \\
\text { offspring }\left(\leftrightarrow 3^{\prime} \mathrm{CpG} \uparrow\right. \\
\text { histone H3K9 acetylation } \\
\text { in high vs low LG-ABN } \\
\text { offspring } \uparrow \text { NGFI-A binding } \\
\text { to exon } 1_{7} \text { GR promoter in } \\
\text { high vs low LG-ABN } \\
\text { offspring } \uparrow \text { GR mRNA in } \\
\text { high vs low } \\
\text { LG-ABN offspring } \uparrow \text { CBP } \\
\text { associated with exon } 1_{7} \\
\text { GR promoter in high vs } \\
\text { low LG-ABN offspring }\end{array}$ \\
\hline
\end{tabular}

Determine strain- $\quad$ C57BL/6 J and MS: PND9, $24 \mathrm{~h}$ specific epigenetic al- DBA/2 J separationAssessed: terations of MS in mice miceHippocampus 11-12 weeks

Determine the effect of Sprague Dawley MS on exon $1_{7}$ GR promoter methylation ratsHippocampus

MS: PND2-14, 3 h/ dayAssessed: PND21

\section{GR gene} locus (7 million base pairs)

Determine the effect maternal care on DNA methylation and H3K9 acetylation of a region of Chr 18 containing the $\mathrm{Nr} 3 \mathrm{Cl}$ gene

\section{Long-Evans RatsHippocampus \\ High vs low LG- ABNAssessed: PND90}

\section{Crh promoter \\ Determine the effect of MS on Crh promoter methylation \\ MS: PND2-13, 4 h/dayAssessed: PND61}

Determine the effect of MS on Crh promoter methylation
Sprague Dawley ratsHippocampus CA1

\begin{tabular}{|c|c|c|c|}
\hline Crfr2 & $\begin{array}{l}\text { Determine the effect of } \\
\text { MS on Crfr2 } \\
\text { methylation }\end{array}$ & $\begin{array}{l}\text { C57BI/6 } \\
\text { miceGenomic } \\
\text { DNA from sperm } \\
\text { in F1 and F2 } \\
\text { malesCortex in F2 } \\
\text { females }\end{array}$ & $\begin{array}{l}\text { Unpredictable MS: } \\
\text { PND1-14, } 3 \text { h/day } \\
\text { in F1Assessed: } \\
3-8 \text { months of age }\end{array}$ \\
\hline $\begin{array}{l}\text { up } \\
\text { hhancer }\end{array}$ & $\begin{array}{l}\text { Determine the effect of } \\
\text { MS on Avp enhancer }\end{array}$ & $\begin{array}{l}\text { C57Bl/6 micePVN } \\
\text { of hypothalamus }\end{array}$ & $\begin{array}{l}\text { MS: PND1-10, } 3 \\
\text { h/daysAssessed: }\end{array}$ \\
\hline
\end{tabular}
dayAssessed: 10 weeks of age
MS: PND1-10, $3 \mathrm{~h} /$ $\leftrightarrow \mathrm{Nr} 3 \mathrm{c} 1$ methylation in C57BL/6J mice $\uparrow \mathrm{Nr} 3 \mathrm{cl}$ CpG 13,14 and 17 methylation in MS-treated DBA/2J mice

$\leftrightarrow$ methylation of exon 17 GR promoter or NGFI-A binding site $\uparrow$ NGF mRNA $\exp \mathrm{NT}-3$

723 RDme and 471 RDac in GR gene were identified across the entire locus in high vs low revealed changes in exp of Pcdh family genes. 20 out of 33 had $\uparrow$ exp in high compared to low LG-ABN offspring

$\downarrow$ methylation of $\mathrm{Crh}$ promoter in hypothalamus (Met-C2) $\downarrow$ methylation of Met-C2 $\uparrow$ phosphoCREB binding to CRH CRE $\uparrow$ Crh hnRNA exp in hypothalamus ( $\leftrightarrow$ amygdala) $\leftrightarrow$ Crh mRNA exp in hypothalamus and amygdala

$\uparrow \mathrm{H} 3$ acetylation of the $\mathrm{Crh}$ promoter in MS vs no MS pups $\downarrow$ methylation and $\downarrow$ binding of MeCP2 in the Crh promoter $\uparrow$ Crh mRNA in MS vs no MS pupsEnriched environment reversed the epigenetic up-regulation of $\mathrm{Crh}$

F1 $\downarrow$ methylation of $5^{\prime} \mathrm{CpG}$ of Crfr2 in MF2 ${ }^{\mathrm{a}} \downarrow$ methylation of $5^{\prime} \mathrm{CpG}$ of Crfr2 in FChanges in gene exp were accompanied by $\downarrow$ mRNA exp

$\downarrow$ Avp enhancer methylation at 6 weeks, 3 months and 1 year $\downarrow$
LG-ABNClustering patterns
MS in DBA/2J mice $\uparrow$ methylation of $\mathrm{CPG} 13,14$ and 17 in $\mathrm{Nr3c} 1$ at

3 months of age

No effect of MS on methylation status of exon 17 of the GR promoter or the NGFI-A binding site in hippocampus

Identified that variations in maternal care affect a broad genomic region and epigenetic and exp changes act on a family of genes localised in that broad genomic regionFinding of the association of the Pcdh cluster of genes involved in synaptic plasticity

MS $\downarrow$ methylation of Met-C2 and $\uparrow$ transcriptional activity of Crh in the PVN on PND6

MS $\uparrow$ acetylation of the Crh promoter region thereby allowing for increased transcriptional activity of Crh which was reversed when mice were treated to enriched environment

Early stress $\downarrow$ methylation of Crfr2 and mRNA exp in adult C57/BL6 mice and that is transmitted across generations

MS causes $\downarrow$ methylation of the Avp enhancer from 6 weeks of age in C57/BL6
$[20,43]$

PND10, 6 weeks, 
Table 2 Early stress-induced epigenetic changes in stress-regulatory genes in animal studies (Continued)

\begin{tabular}{|c|c|c|c|c|}
\hline $\begin{array}{l}\text { methylation and mRNA } \\
\text { exp }\end{array}$ & & $\begin{array}{l}3 \text { months and } \\
1 \text { year }\end{array}$ & $\begin{array}{l}\text { methylation of CpGs } \\
\text { largely mapped to CG13 of } \\
\text { Avp enhancer from } \\
6 \text { weeks ( } \leftrightarrow \text { at PND10) } \downarrow \\
\text { binding of CG13 Avp } \\
\text { enhancer at PND10 and } \\
6 \text { weeks } \downarrow \text { methylation of } \\
\text { CpGs } w \text { age (11 CpGs at } \\
6 \text { weeks, } 7 \text { at } 3 \text { months, } 3 \\
\text { at } 1 \text { year) } \uparrow \text { AVP mRNA exp } \\
\text { from } 6 \text { weeks }\end{array}$ & $\begin{array}{l}\text { mice which is } \\
\text { accompanied by persistent } \\
\text { up-regulation of Avp exp in } \\
\text { parvocellular neurons in } \\
\text { the PVN }\end{array}$ \\
\hline $\begin{array}{l}\text { Determine } \\
\text { strain-specific } \\
\text { epigenetic alterations } \\
\text { of MS in mice }\end{array}$ & $\begin{array}{l}\text { C57BL/6J and } \\
\text { DBA/2J } \\
\text { miceHippocampus }\end{array}$ & $\begin{array}{l}\text { MS: PND9, 24-h } \\
\text { separationAssessed: } \\
\text { 11-12 weeks }\end{array}$ & $\begin{array}{l}\uparrow \text { methylation of CpG1 of } \\
\text { Avp in MS treated M of } \\
\text { C } 57 \mathrm{BL} / 6 \mathrm{~J} \text { and DBA/2J } \\
\text { strain }\end{array}$ & $\begin{array}{l}\text { MS } \uparrow \text { methylation of } C p G 1 \\
\text { unit in the Avp enhancer } \\
\text { DNA sequence }\end{array}$ \\
\hline
\end{tabular}

$\uparrow$ increased, $\downarrow$ decreased, $\leftrightarrow$ no change, Avp arginine vasopressin, CBP CREB binding protein, Crfr2 corticotrophin-releasing hormone receptor $2, C r h$ corticotrophin-releasing hormone, exp expression, $F$ female, $G R$ glucocorticoid receptor, $h$ hour, $h n R N A$ heterogeneous nuclear ribonucleic acid, $L G$ - $A B N$ licking grooming arched-back nursing, $M$ male, $m R N A$ messenger ribonucleic acid, $M S$ maternal separation, NGF nerve growth factor, NGFI- $A$ nerve growth factor inducible protein A, NT3 neurotophin 3, PND postnatal day, PVN paraventricular nucleus, RDac regional differences in acetylation, RDme regional differences in methylation, Pcdh: Protocadherin, CA-1 Cornu Ammonis area 1, MeCP2 Methyl CpG binding protein 2

${ }^{\mathrm{a}} \mathrm{F} 2$ : MS $\mathrm{M}$ and control $\mathrm{F}$ were bred to produce $\mathrm{F} 2$ offspring

promoter and decreased H3K9 acetylation both associated with reduction in GR messenger RNA (mRNA) expression in the hippocampus of pups raised by low licking grooming arched-back nursing (LG-ABN) dams [20]. Extended studies showed that increased $5^{\prime}$ cytosine phosphate guanine $(\mathrm{CpG})$ site methylation in the low LG-ABN pups reduced binding of transcription factor nerve growth factor inducible protein A (NGFI-A) to GR exon $1_{7}$ promoter and reduced recruitment of CREB binding protein (CBP), subsequently reducing the levels of GR mRNA in hippocampus [20,43]. These changes were observed both at postnatal day (PND) 6 (early) and PND90 (adulthood) suggesting the long-lasting nature of the epigenetic mark. In contrast, Daniels and colleagues reported no differences in the methylation status of exon $1_{7}$ GR promoter in maternally separated (MS) compared to control rats on PND21 [44]. The conflicting results could be due to differences in the early stress model (maternal care vs MS) and strain (Long-Evans vs Sprague Dawley) which may exert different effects on the epigenetic signature of the glucocorticoid receptor. Other studies also report epigenetic alterations in the GR promoter using different ELS models of rat/mouse strains $[45,46]$ (Table 2).

\section{Crh}

Chen and colleagues reported hypomethylation of the Crh promoter in the PVN of maternally deprived (MD) Sprague Dawley rats on PND61 [47]. This was associated with increased phosphoCREB binding to the Crh cAMP response element (CRE), critical in the regulation of transcription of Crh. Similarly, Wang and colleagues reported increased $\mathrm{H} 3$ acetylation and hypomethylation of the Crh promoter region in the hippocampal cornu ammonis 1 (CA1) region of rats with postnatal MS [48].
Franklin and colleagues reported hypomethylation of the CRH receptor $2(\mathrm{Crhr} 2)$ in maternally separated male C57/BL6 mice at 3-8 months of age and demonstrated a transgenerational effect [21]. The hypomethylation was associated with decreased $\mathrm{Crhr} 2$ gene expression which in this case was assessed in vitro using zebularine, a DNA methylation inhibitor [21]. This is in contrast to conventional understanding that DNA methylation is repressive $[49,50]$; however, results correlate with the expected ELS-induced changes in HPA axis regulation and decreased Crhr2 expression.

\section{Avp}

Murgatroyd and colleagues reported hypomethylation of the AVP enhancer sequence in the parvocellular neurons of the PVN [23]. Hypomethylation of the AVP enhancer was associated with increased $A v p$ expression following ELS (maternal separation) from 6 weeks of age and was still evident at 1 year suggesting the long-lasting nature of this epigenetic mark. Mechanistic analysis using mouse hypothalamic-like cells revealed that the hypomethylated $\mathrm{CpG}$ sites bound MeCP2 during postnatal life that in turn recruited DNA methyl transferase (DNMTs) and histone deacetylase (HDACs) to regulate expression of Avp [23] and that MeCP2 occupancy further depended on polycomb binding earlier in hypothalamic development [51]. Contrasting results were reported in a more recent study showing hypermethylation of the $A v p$ enhancer $\mathrm{CpG}$ site in the hippocampus of maternally deprived $\mathrm{C} 57 \mathrm{BL} / 6$ and DBA/2 males [45]. This could be due to the type of tissue analysed and the fact that the $\mathrm{CpG}$ sites analysed by these two studies did not overlap. 
Table 3 Early stress-induced epigenetic modifications in other candidate genes

\begin{tabular}{|c|c|c|c|c|c|c|}
\hline $\begin{array}{l}\text { Candidate } \\
\text { gene }\end{array}$ & Objective & Model/tissue type & $\begin{array}{l}\text { Early stress/assessment } \\
\text { age }\end{array}$ & $\begin{array}{l}\text { Epigenetic and expression } \\
\text { changes }\end{array}$ & Interpretation & References \\
\hline$E r-a$ & $\begin{array}{l}\text { Determine the } \\
\text { effect of } \\
\text { maternal care } \\
\text { on Er-a mRNA } \\
\text { exp and Era1b } \\
\text { promoter } \\
\text { methylation }\end{array}$ & $\begin{array}{l}\text { Long-Evans hooded } \\
\text { ratsMPOA of } \\
\text { Amygdala }\end{array}$ & $\begin{array}{l}\text { Maternal care variations: } \\
\text { high vs low LG- } \\
\text { ABNAssessed: PND6 }\end{array}$ & $\begin{array}{l}\downarrow \text { Era1b promoter } \\
\text { methylation in high vs low } \\
\text { LG-ABN offspring } \uparrow \text { Stat5 } \\
\text { binding to Era1b promoter } \\
\text { in high vs low LG-ABN } \\
\text { offspring } \uparrow \text { Er-a mRNA exp } \\
\text { in high vs low LG-ABN } \\
\text { offspring }\end{array}$ & $\begin{array}{l}\text { Higher levels of maternal } \\
\text { care cause } \downarrow \text { Era } 1 b \\
\text { promoter methylation, } \\
\uparrow E r-a \text { mRNA exp and } \uparrow \\
\text { Stat5 binding to Era1b } \\
\text { promoter in the MPOA in } \\
\text { Long-Evans hooded rats } \\
\text { on PND6 }\end{array}$ & [59] \\
\hline \multirow[t]{2}{*}{ 5-HTT } & $\begin{array}{l}\text { Determine the } \\
\text { relationship } \\
\text { between early } \\
\text { stress and 5-HTT } \\
\text { gene } \\
\text { methylation }\end{array}$ & $\begin{array}{l}\text { Rhesus } \\
\text { macaquesPeripheral } \\
\text { blood DNA }\end{array}$ & $\begin{array}{l}\text { Rearing variations: MR vs } \\
\text { NRAssessed: } 90-120 \text { days } \\
\text { (infants) }\end{array}$ & 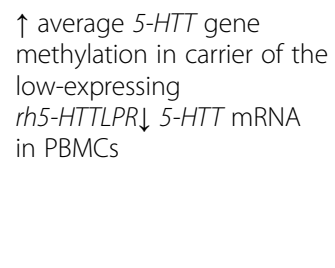 & $\begin{array}{l}\text { Variations in maternal } \\
\text { care were associated with } \\
\text { average differences in } \\
\text { 5-HTT gene methylation } \\
\text { and this was dependent } \\
\text { on the 5-HTT } \\
\text { polymorphism in Rhesus } \\
\text { macaques }\end{array}$ & {$[57]$} \\
\hline & $\begin{array}{l}\text { Determine the } \\
\text { effect of early } \\
\text { stress on 5-HTT } \\
\text { gene and whole } \\
\text { genome DNA } \\
\text { methylation }\end{array}$ & $\begin{array}{l}\mathrm{F} \text { bonnet } \\
\text { macaquesPeripheral } \\
\text { blood DNA }\end{array}$ & $\begin{array}{l}\text { VFD from } 3-8 \text { months } \\
\text { ageAssessed: } \text { mean = } \\
8.4 \text { years }\end{array}$ & $\begin{array}{l}\leftrightarrow 5 \text {-HTT and whole } \\
\text { genome methylation } \uparrow \\
\text { 5-HTT and whole genome } \\
\text { methylation } \uparrow \text { stress } \\
\text { reactivity in VFD }\end{array}$ & $\begin{array}{l}\text { 5-HTT gene and whole } \\
\text { genome methylation } \\
\text { confer an } \uparrow \text { stress } \\
\text { reactivity following early } \\
\text { stress in adolescent } F \\
\text { bonnet macaques }\end{array}$ & [58] \\
\hline Gad1 & $\begin{array}{l}\text { Determine the } \\
\text { effect of } \\
\text { maternal care } \\
\text { on the Gad1 } \\
\text { promoter in the } \\
\text { hippocampus }\end{array}$ & $\begin{array}{l}\text { Long-Evans hooded } \\
\text { ratsHippocampus }\end{array}$ & $\begin{array}{l}\text { Maternal care variations: } \\
\text { high vs low LG- } \\
\text { ABNAssessed: } 3-4 \text { months } \\
\text { of age except for NGFI-A } \\
\text { association to Gad1 pro- } \\
\text { moter at PND4 }\end{array}$ & $\begin{array}{l}\downarrow \text { methylation of Gad1 } \\
\text { promoter in high vs low } \\
\text { LG-ABN offspring } \uparrow \text { histone } \\
\text { H3K9 acetylation of Gad1 } \\
\text { promoter in high vs low } \\
\text { LG-ABN offspring } \uparrow \text { NGFI-A } \\
\text { association w Gad? } \\
\text { promoter in high vs low } \\
\text { LG-ABN offspring } \uparrow \text { Gad1 } \\
\text { mRNA exp in high vs low } \\
\text { LG-ABN offspring }\end{array}$ & $\begin{array}{l}\text { High levels of maternal } \\
\text { care } \downarrow \text { Gad1 promoter } \\
\text { methylation, } \uparrow \text { Gad } 1 \\
\text { promoter histone } \\
\text { acetylation and } \uparrow \text { Gad } 1 \\
\text { mRNA in the } \\
\text { hippocampus of } \\
\text { Long-Evans hooded rats }\end{array}$ & {$[66]$} \\
\hline \multirow[t]{3}{*}{ Bdnf } & $\begin{array}{l}\text { Determine the } \\
\text { effect of early } \\
\text { stress on DNA } \\
\text { methylation }\end{array}$ & $\begin{array}{l}\text { Long-Evans hooded } \\
\text { ratsHippocampus } \\
\text { and PFC }\end{array}$ & $\begin{array}{l}\text { Exposure to abusive or } \\
\text { caring mother from } \\
\text { PND1-7 for } \\
30 \text { minAssessed: PND8, } \\
30 \text { and } 90\end{array}$ & $\begin{array}{l}\uparrow \text { methylation of } B d n f \text { exon } \\
\text { IV and IX in PFC } \text { Bdnf } \\
\text { mRNA exp in PFC } \uparrow \text { Bdnf } \\
\text { mRNA exp in hippocampus }\end{array}$ & $\begin{array}{l}\text { Early abuse } \uparrow \text { methylation } \\
\text { of } B d n f \text { exon IV and IX in } \\
\text { the PFC that persists into } \\
\text { adulthood in Long-Evans } \\
\text { hooded rats }\end{array}$ & [53] \\
\hline & \multirow{2}{*}{$\begin{array}{l}\text { Determine the } \\
\text { effect of early } \\
\text { stress on Bdnf } \\
\text { mRNA, protein } \\
\text { and miR-16 exp }\end{array}$} & \multirow[t]{2}{*}{$\begin{array}{l}\text { Sprague Dawley } \\
\text { ratsHippocampus }\end{array}$} & \multirow{2}{*}{$\begin{array}{l}\text { MS: PND1-13CUPS: 10- } \\
13 \text { weeksC: no } \\
\text { stressAssessed: 13- } \\
14 \text { weeksOnly Bdnf } \\
\text { transcribed from 5' exon } \\
\text { VI and 3' common exon } \\
\text { analysed }\end{array}$} & \multirow{2}{*}{$\begin{array}{l}\downarrow B d n f \text { mRNA exp in MS vs } \\
\text { CUPS and C } \downarrow \text { Bdnf protein } \\
\text { in MS vs CUPS and C } \uparrow \text { miR- } \\
16 \text { exp in MS vs CUPS and } \\
C \downarrow B d n f \text { mRNA exp in MS } \\
\text { correlated significantly with } \\
\uparrow \text { miR-16 exp }\end{array}$} & $\begin{array}{l}\text { MS induced significantly } \\
\text { different BDNF and miR- } \\
16 \text { expression in rats. }\end{array}$ & \multirow[t]{2}{*}[54]{} \\
\hline & & & & & $\begin{array}{l}\text { BDNF and miR-16 levels } \\
\text { were inversely related in } \\
\text { the presence of early } \\
\text { stress }\end{array}$ & \\
\hline $\begin{array}{l}\text { Reelin } \\
\text { (Reln) }\end{array}$ & $\begin{array}{l}\text { Determine the } \\
\text { effect of MS on } \\
\text { Reln expression }\end{array}$ & $\begin{array}{l}\text { Wistar } \\
\text { ratsHippocampus }\end{array}$ & $\begin{array}{l}\text { MS: PND2-15 for } \\
3 \text { hAssessed: PND22 }\end{array}$ & $\begin{array}{l}\uparrow \text { Reln gene methylation } \downarrow \\
\text { Reln mRNA exp }\end{array}$ & $\begin{array}{l}\text { MS } \uparrow \text { Reln gene } \\
\text { methylation and } \downarrow \text { Reln } \\
\text { mRNA exp in Wistar rats } \\
\text { on PND22 }\end{array}$ & {$[67]$} \\
\hline
\end{tabular}

$\uparrow$ increased, $\downarrow$ decreased, $\leftrightarrow$ no change, 5 -HTT serotonin transporter, PND postnatal day, Bdnf brain-derived neurotrophic factor, DNA deoxyribonucleic acid, Er- $a$ estrogen receptor alpha, exp expression, $F$ female, Gad1 glutamic acid decarboxylase 1, LG-ABN licking grooming arched-back nursing, MPOA medial preoptic area, $M R$ mother reared, NR nursery reared, $m R N A$ messenger ribonucleic acid, PBMC peripheral blood mononuclear cells, VFD variable foraging demand, MS maternal separation, NGFI-A nerve growth factor inducible protein A, PFC prefrontal cortex, PND postnatal day, Stat5 signal transducer and activator of transcription 5 , mi- $R$ micro-RNA, CUPS chronic unpredictable stress, $C$ control

\section{ELS-induced epigenetic changes in genes outside of the HPA axis}

Brain-derived neurotrophic factor

ELS has been shown to decrease $B d n f$ expression whilst enhancing anxiety and depression-like behaviours [41, 52]. Roth and colleagues exposed Long-Evans rat pups to an abusive mother during the first week of life [53]. They reported hypermethylation of the $B d n f$ exons IV and IX in the prefrontal cortex on PND8 with associated reduction of $B d n f$ mRNA which persisted into adulthood. Bai and colleagues reported significantly decreased $B d n f$ mRNA and protein and increased miR-16 
expression in the hippocampus of MD rats compared to those exposed to chronic unpredictable stress in adulthood (CUPS) and control rats [54] (see Table 3). The results suggested significant association of depression induced by MD to $B d n f$ and miR-16 levels but not the late-life stressors such as the CUPS thus emphasising the role of ELS-induced epigenetic alterations.

\section{Serotonin transporter (5-HTT or Slc6a4) gene}

Reduction in 5-HTT expression has been observed in response to ELS in non-human primate and rodent models $[55,56]$. Kinnaly and colleagues investigated the role of ELS-induced epigenetic modifications in the 5HTT gene using non-human primate models [57, 58] (see Table 3). These studies assessed the relationship between 5-HTT expression and 5-HTT gene methylation following ELS in infant rhesus macaques [57] and adolescent bonnet macaques [58]. No significant effect of rearing was observed on the 5-HTT methylation status in either study. However, carriers of the short allele of the 5-HTT polymorphism had higher mean 5-HTT CpG methylation, and this was significantly associated to the levels of peripheral 5-HTT expression in the infant rhesus macaques [57]. In adolescent and adult Bonnet macaques, genome-wide methylation levels were associated with 5-HTT expression in those exposed to early stress as infants compared to controls [58]. The above studies suggest that 5-HTT gene methylation is not susceptible to variations in maternal care; however, polymorphisms in the 5-HTT gene and methylation at other cis or Trans regulating sites as may be conferring increased stress reactivity.

\section{Estrogen receptor-a gene}

Increased expression of estrogen receptor- $\alpha(E R \alpha)$ in response to variations in maternal care was first reported by Champagne and colleagues using the LG-ABN rat model [39]. The study reported elevated ER $\alpha$ mRNA expression in the medial preoptic area of high LG-ABN dams compared to low LG-ABN, and this effect was transmitted to the female offspring of the high LG-ABN dams $[39,59]$. Champagne and colleagues then demonstrated decreased ER $1 \mathrm{~b}$ promoter methylation in high vs low LG-ABN offspring on PND6 [59] (Table 3). It was characterised that this hypomethylation of the promoter region enhanced binding of the STAT5 transcription factor to the ER $\alpha 1 b$ promoter and a corresponding increase in ER $\alpha$ mRNA expression in response to increased maternal care.

\section{Glutamate decarboxylase-1 and Reelin genes}

Glutamate decarboxylase 1 (GAD1) is a key enzyme in the synthesis of gamma amino-butyric acid (GABA), and Reelin (Reln) is important in migration of new neurons in the central nervous system (CNS). Postmortem studies of schizophrenic patient brains have shown decreased forebrain expression of GAD1 [60,61] and increased methylation of the GAD1 promoter $[62,63]$ and decreased RELN expression [64, 65]. Zhang and colleagues assessed the methylation status of the Gad1 promoter in the offspring of the high vs low LG-ABN dams [66] (See Table 3). Hypomethylation, increased histone H3K9 acetylation and increased NGFI-A association with the Gad1 promoter were observed in those raised by high LG-ABN dams leading to increased Gad1 mRNA expression [66]. Qin and colleagues reported hypermethylation of the Reln gene and subsequent down-regulation of Reln mRNA in the hippocampus of Wistar rats exposed to MS from PND2-15 compared to controls [67].

\section{Early stress-induced epigenetic modifications in humans}

Epigenetic alterations in candidate genes

In human studies, most focus to date has been on the role of GR due to its negative feedback control in stress responsivity and serotonin transporter $(5-H T T)$ due to its polymorphisms and role in mediating ELS and laterlife stress effects on adult depression status $[14,68]$ (see Table 4 for summary of studies).

\section{GR gene}

McGowan and colleagues were the first to demonstrate hypermethylation of the GR promoter exon $1_{\mathrm{F}}$ and decreased GR mRNA in the hippocampus of adults who were exposed to childhood abuse [19]. When compared to suicide victims or controls with no childhood abuse the GR promoter of suicide victims with a history of childhood abuse showed a significant increase $(p<0.05$; $d=1.07$ ) in methylation. This study was thus able to translate the results previously described in LG-ABN rat model [43]. McGowan and colleagues extended research by analysing a wider locus containing the GR gene on chromosome 5 and reported differential methylation in promoters of the protocadherin $(P C D H)$ gene family which are implicated in synaptic plasticity [69]. Whilst McGowan and colleagues analysed the epigenetic changes in hippocampal GR gene, other human studies have reported similar hypermethylation GR gene promoter in peripheral blood leukocytes of adults exposed to early childhood stress [70, 71]. Murgatroyd and colleagues have recently demonstrated maternal stroking to modify $\mathrm{CpG}$ methylation within this GR region further translating the rat LG results [72]. These studies have shown that hypermethylation of specific CpG sites were associated to type of early stress or the severity of early maltreatment (see Table 4). 
Table 4 Early stress-induced epigenetic modifications of candidate genes in humans

Candidate Objective Model/tissue type Early stress/assessment age

\section{gene}

rRNA

promoter Determine the effect of RetrospectiveHippocampus childhood abuse on methylation status of the rRNA promoter

CA+suicide vs no CA+no

Epig

Epigenetic and expression changes

Interpretation

Childhood abuse $\uparrow$ methylation of rRNA
promoter in the hippocampus of suicide

CA + suicide vs no CA + no
suicideAssessedMean age 35 yrs. $N=30$

GR promoter

Determine the effect of RetrospectiveHippocampus Child abuseAssessedMean childhood abuse on the methylation status of the GR promoter

and GR mRNA exp

Determine the effect of RetrospectivePeripheral early stress on blood WBCs methylation status of

the GR promoter

Determine the effect of RetrospectivePeripheral childhood blood WBCs

maltreatment and

severity on NR3C1

promoter methylation age $34.6 \mathrm{yrs} . \mathrm{N}=36 \mathrm{M}$

$\uparrow$ methylation rRNA promoter and $5^{\prime}$ regulatory region in CA $\uparrow$ methylation of 21 promoter in the hippocam
of $26 \mathrm{CpG}$ sites in CA $\downarrow$ rRNA expression in
completers in adulthood hippocampus

$\uparrow$ methylation of CpGs in GR promoter $\downarrow$ GR mRNA exp $\downarrow$ GR $1 F$ mRNA exp

Childhood abuse $\uparrow$ methylation of individual CPGs within the GR promoter and GR1F exon resulting in $\downarrow$ GR and GR $1 \mathrm{~F}$ mRNA expression in adult hippocampus

Early stress ${ }^{\mathrm{a}} \mathrm{Assessed:}$ mean age 27.4 yrs. $N=99$

Childhood

maltreatment ${ }^{\mathrm{b}}$ Assessed: mean ages and sample sizeBPD 30.76 yrs. $N=$ 101MDD 41.63 yrs. N= 99MDD + PTSD $37.33 \mathrm{yrs}$ $N=15$

Determine the effect of RetrospectiveHippocampus

base pairs) centred on NR3Cl

5HTT or Determine the effect of RetrospectivePeripheral SLC6A4 CA on SLC6A4 blood DNA promoter methylation blood DNA $\quad$ adversity $^{\mathrm{a}}$ Assessed: and mRNA expression adulthood $N=102 \mathrm{MDD}$ with or without $C A$

CA + suicide vs no CA + no
suicideAssessed: adulthood $N=24$

Determine the effect of RetrospectiveLymphoblast CA on the methylation cell lines

status of SLC6A4

Childhood

promoter $\uparrow$ CpG1 methylation $w \downarrow$ parental care or loss $\uparrow \mathrm{CpG} 3$ methylation w maltreatment or parental loss $\leftrightarrow$ CpG2, 4, 5-13 methylation $w$ childhood adversity

$\uparrow$ CpG 2-8 methylation of the NR3C1 gene promoter in maltreated participants $\uparrow$ severity of maltreatment $\uparrow$ methylation status of NR3Cl except for CPGl site Early stress $\uparrow$ methylation of individual
CpGs of the GR promoter in adulthood Childhood maltreatment was associated with $\uparrow$ methylation of the $\mathrm{NR3Cl}$ gene promoter in peripheral blood in adulthood.Number and severity of maltreatment correlated positively with methylation status

281 DMRs were identified $\uparrow$ methylation in 126 DMRs in controls $\uparrow$ methylation in 155 within $\alpha$-, $\beta$ - and $\gamma$ - protocadherin $(P C D H)$ gene familyDMRs enriched more in a-PCDH in the abused brains

$\uparrow$ average methylation in promoter of SLC6A4 with CpG7 showing higher methylation in CA to no CA $\uparrow$ methylation in CpG2 of SLC6A4 associated with physical abuse

$\uparrow$ overall SLC6A4 promoter methylation in abused male and female $\uparrow$ methylation of CpG1 and CpG 3 of SLC6A4 in abused

females compared to non-abused $\leftrightarrow$ in

individual $\mathrm{CpG}$ sites in males

Early stress has a broader epigenomics mprint expanding to promoters of genes both upstream and downstream to the $N R 3 C 1$ gene and includes the PCDH gene amily implicated in synaptic plasticity

Childhood adversities were significantly associated with higher SLC6A4 promoter

Childhood abuse increased methylation of CpGs in the promoter of SLC6A4 in adults DMRs in abused3 clusters of DMRs mapped methylation in people with current MDD

$\uparrow$ increased, $\downarrow$ decreased, $\leftrightarrow$ no change, yrs. years, CA child abuse, DNA deoxyribonucleic acid, mRNA messenger ribonucleic acid, exp expression, rRNA ribosomal ribonucleic acid, GR glucocorticoid receptor, $M$ male, $F$ Female, WBC white blood cell, $B P D$ borderline personality disorder, $P T S D$ post-traumatic stress disorder, $M D D$ major depressive disorder, DMRs differentially methylated regions, $P C D H$ protocadherin, NR3C1 nuclear receptor subfamily 3, group C, member 1, SLC6A4 solute carrier family 6, member 4 (neurotransmitter transporter)

${ }^{a}$ Early stress included: low levels of parental care, parental loss and childhood maltreatment

${ }^{b}$ Sexual, physical and emotional abuse; BPD had higher childhood maltreatment; MDD had lower maltreatmen 
Table 5 Effects of early stress on genome-wide methylation in humans

\begin{tabular}{|c|c|c|c|c|c|}
\hline Objective & Model/tissue type & $\begin{array}{l}\text { Early stress/ } \\
\text { assessment age }\end{array}$ & $\begin{array}{l}\text { Epigenetic and expression } \\
\text { changes }\end{array}$ & Interpretation & References \\
\hline $\begin{array}{l}\text { Determine the effect } \\
\text { of childhood SES on } \\
\text { genome-wide } \\
\text { methylation in } \\
\text { adulthood }\end{array}$ & $\begin{array}{l}\text { RetrospectivePeripheral } \\
\text { blood DNA }\end{array}$ & $\begin{array}{l}\text { High vs low } \\
\text { childhood } \\
\text { SESAssessed: } \\
45 \text { yrs. } N=40 \mathrm{M}\end{array}$ & $\begin{array}{l}666 \text { gene promoters } \uparrow \text { and } \\
586 \text { promoters } \downarrow \text { methylation } \\
\text { in high vs low childhood } \\
\text { SESThe genes involved fall } \\
\text { into extra and intracellular } \\
\text { signalling, DNA signalling and } \\
\text { metabolic signalling } \\
\text { categories. }\end{array}$ & $\begin{array}{l}\text { Variations in childhood SES } \\
\text { cause changes in } \\
\text { genome-wide methylation in } \\
\text { adulthood with genes in extra } \\
\text { and intra cellular signalling } \\
\text { and metabolic functioning }\end{array}$ & [79] \\
\hline $\begin{array}{l}\text { Determine the effect } \\
\text { of early environment } \\
\text { on genome-wide } \\
\text { methylation levels }\end{array}$ & $\begin{array}{l}\text { RetrospectivePeripheral } \\
\text { blood DNA }\end{array}$ & $\begin{array}{l}\text { Institutional care } \\
\text { vs raised by } \\
\text { biological } \\
\text { parentsAssessed: } \\
\text { mean } 8.25 \text { yrs. } N \\
=28\end{array}$ & $\begin{array}{l}\text { Differential methylation of } 914 \\
\text { of } 26,214 \text { CpG sites from } 838 \\
\text { gene promoters across } \\
\text { groups }{ }^{\mathrm{a}} \uparrow \text { methylation of } 744 \\
\text { promoters in institutionalised } \downarrow \\
\text { methylation of } 94 \text { promoters } \\
\text { in institutionalisedPromoters }\end{array}$ & $\begin{array}{l}\text { Early environmental alterations } \\
\text { cause changes in methylation } \\
\text { of a number of genes } \\
\text { important for control of } \\
\text { cellular signalling and the } \\
\text { immune response in } \\
\text { childhood }\end{array}$ & [77] \\
\hline
\end{tabular}

Determine the effect of childhood abuse on genome-wide DNA methylation

$\begin{array}{ll}\text { RetrospectiveHippocampus } & \text { CA + suicide vs } \\ & \text { no CA + } \\ & \text { suicideAssessed: } \\ & \text { adulthood } N=41 \\ & \text { M }\end{array}$
cellular signalling and the immune response

Differentially methylated promoters in CA vs no CA were spread across the genome248 (68.5\%) promoters $\uparrow$ methylation in CA114 (31.5\%) promoters $\downarrow$ methylation in CA $\uparrow$ methylation associated $\mathrm{w} \downarrow$ mRNA exp

RetrospectivePeripheral blood DNA

Determine the effect of childhood abuse in methylation status of immune system and cytokine regulation
RetrospectivePeripheral blood DNA

$$
\begin{aligned}
& \text { PTSD }+ \text { CA vs } \\
& \text { PTSD + no } \\
& \text { CAAssessed: } \\
& \text { mean age CA }= \\
& \text { 39.6 yrs.No CA = } \\
& 43.69 \mathrm{~N}=61
\end{aligned}
$$

Differential methylation in promoters of abused vs non-abused PTSD patients $\uparrow$ methylation in transcripts of PTSD + CA group (11.78\%) vs PTSD + no CA (0.8 \%) 14 transcripts differentially methylated in CA vs no CA

PTSD + CA, PTSD $\uparrow$ global methylation in PTSD
+ no CA, C + CA, vs C $\leftrightarrow$ methylation due to CA + no $C A, C+C A$, $\mathrm{C}+$ no CAAssessed: adulthood $N=$ 110 in PTSD or CGene specific associations with found in BDNF, HSF1, TLR8 for PTSD and CA plasma TNFa in CA vs no
Childhood abuse causes alteration in the methylation of gene promoters and mRNA exp in adulthood specifically genes involved in neuronal plasticity

Childhood abuse causes alteration to the methylation of $\mathrm{CpG}$ sites in both promoter regions and gene body and include specifically genes involved in CNS development in the abused PTSD group

Childhood abuse early in life can alter global and gene specific DNA methylation patterns specifically involved in immune dysregulation

\author{
CA
}

$\uparrow$ increased, $\downarrow$ decreased, $\leftrightarrow$ no change, yrs years, SES socioeconomic status, $M$ Male, DNA deoxyribonucleic acid, $m R N A$ messenger ribonucleic acid, exp expression, CA childhood abuse, PTSD post-traumatic stress disorder, $C$ controls, BDNF brain-derived neurotrophic factor, HSF1 heat shock transcription factor 1 , TLR8 toll-like receptor 8, TNFa tumour necrosis factor alpha, CNS central nervous system

${ }^{a}$ Genes modified by rearing environment include those involved in control of the dopaminergic system (TERF2IP), serotonin biosynthesis and serotonin receptor activity (TPH, HTR1D, HTR1F), glucocorticoid and steroid biosynthesis and their receptor activity (NRIP1, PPARGC1B, UGT), genes encoding the arginine vasopressin receptor, glutamate, cadherin and cholinergic receptors, and others which are collectively responsible for neural communication, memory formation and learning and retention

\section{5-HTT gene}

Philibert and colleagues were the first to report hypermethylation of the 5-HTT promoter and subsequent reduction in 5-HTT mRNA; however, this study did not assess the role of early maltreatment [73]. Further work from Beach and colleagues reported association of increased methylation of the 5-HTT promoter to childhood abuse. In their 2010 study, Beach and colleagues report significant association of overall methylation of the 5-HTT promoter region (CpGs analysed $=71, \mathrm{CpGs}$ used in analyses $=26)$ to childhood abuse $(p<0.0004, d$
$=0.73$ ) [74]. In particular, increased methylation of the sites CpG1 and CpG3 in the 5-HTT promoter was significantly associated in abused females. In their 2011 study, the same group showed significant association of childhood abuse to 5-HTT promoter methylation, 5HTT mRNA levels and a correlation to 5-HTT genotype and adult anti-social personality disorder [75]. The study reported that $9 \%$ of the variation in the personality disorder was attributed to increased 5-HTT promoter methylation observed only in those that were sexually abused (see Table 4 for details). Kang and colleagues also 
reported similar hypermethylation of the 5-HTT promoter (total of seven CpG sites) in abused compared to non-abused people with current MDD [76]. The average methylation percentage of the seven $\mathrm{CpG}$ sites for any adversity was significantly higher in those who were abused in childhood $(p<0.001, d=1.1)$.

\section{Genome-wide methylation}

A number of studies have assessed the effect of early stress on genome-wide methylation patterns (See Table 5 for summary of studies). Naumova and colleagues demonstrated hypermethylation of 28 genes involved in brain development and function including those regulating the arginine vasopressin 1A receptor (AVPR1A), GABA A receptor (GABRA5), glutamate receptor (GRM5), among others, in 7- to 10-year-old children following institutionalisation [77]. Hypermethylation of candidate genes has also been shown in adulthood, with Labonte and colleagues reporting hypermethylation of 248 gene promoters and associated decreases in mRNA expression of these promoters in the hippocampi of adult men who completed suicide [78]. Genes responsible for cellular and neuronal plasticity were the most differentially methylated, including the alsin (ALS2) gene promoter. Many other studies have also shown significant global methylation differences between those exposed to early adversity [79-81]. These studies suggest that alterations in the early environment have the ability to cause changes in the methylation status of numerous genes across the genome, including those involved in control of nervous and immune system development and function.

\section{Discussion}

As evidenced in the studies reviewed above, changes in DNA methylation in response to the early environment remain the best characterised to date. This could be due to DNA methylation being a robust epigenetic mark and available to study across lifespan and generations [21, 82]. More recent studies however have also analysed the role of microRNAs [54], histone modifications [83] and DNA hydroxymethylation [84] in mediating early stress effects.

Results from the animal models reviewed suggest that ELS exerts significant methylation changes in the stressregulatory genes. Enhanced Crh and Avp expression in the hypothalamus may lead to a hypersensitive HPA axis [23, 47], whilst reduced Crhr2 and GR expression (in the hypothalamus and hippocampus respectively) may affect negative feedback of the HPA response to stress [20, 21]. Epigenetic signatures in the GR gene promoter in humans exposed to a variety of early adversity translate the results observed in animal models and confirm the central role of GR methylation in the dysfunctional negative feedback of HPA axis [19, 70, 71]. Analysis of a broader GR locus ( $\sim 7 \mathrm{Mpb}$ centred with $N r 3 c 1)$ in both rats and humans exposed to early adversity revealed conserved methylated sequences in the GR locus including the GR promoter methylations thus emphasising an evolutionary role of the GR locus in stress responsivity [46, 69] (See Tables 2 and 4 for details).

Studies of animal models have centred on other candidate genes implicated in the pathogenesis of neuropsychiatric disorders. Altered 5-HTT expression early in life may moderate the impact of early environment on emotion development [28] as also shown by pharmacological blocking studies $[85,29]$. The findings on 5-HTT promoter methylation therefore support the role of reduced 5-HTT activity in the onset of adult depressionlike behaviours $[57,58]$. Reduced $B D N F$ expression has been implicated in anxiety and depression-like behaviours [41, 52]; therefore, hypermethylation of the $B d n f$ gene alongside reduced $B d n f$ mRNA expression in the prefrontal cortex (PFC) of rats exposed to abuse (67) suggests early stress may play a role in the development of anxiety and depression disorders. In humans exposed to early adversity, 5-HTT hypermethylation has been associated to adult depression status depending on the polymorphic status of the 5-HTT gene, emphasising the role of genetic polymorphisms on epigenetic effects [14, 76]. Interestingly, studies to date have only analysed the effect of prenatal stress on the methylation status of the $B D N F$ gene in humans $[86,87]$ and not variations in postnatal stress. BDNF is known to regulate neuronal development, serotonergic functions and signalling [88]. For example, BDNF promotes the development and function of serotonergic neurons where high affinity receptors for BDNF, Trkb, are also found [89]. Therefore, ELS-induced reduced BDNF could also potentially lead to decreased function of the serotonergic system thus leading to mood and affective behavioural dysfunctions as reported in the above studies. In addition, BDNF has been shown to be regulated by estrogen via $E R \alpha$ within the hippocampus of rat brains [90]. In this context, the increased ER $\alpha$ expression in the brains of the high LG$A B N$ rats [59] suggests that estrogen is important in regulating normal brain development and possibly involves maturation of neural systems via BDNF regulation. The down-regulation of Reelin post ELS [67] may negatively impact hippocampal function, potentially altering stress axis regulation and predisposing to anxiety and depression across the lifespan. A neurodevelopmental origin for schizophrenia is shown from the study suggesting increased methylation and reduced Gad1 expression in rats [66] which fits with the observations in postmortem brains of schizophrenic patients [62, 63].

One of the major questions in psychiatric epigenetics is whether epigenetic changes observed in the periphery 
reflect the changes in the brain. For example, hypermethylation of GR gene promoter and subsequent increase in GR mRNA was reported in both peripheral leukocytes [70, 71] and in the neurons of the hippocampus [19]. Analysis of methylome of cells in the PFC and T cells in mother vs surrogate-reared rhesus macaques revealed similarities in the methylation of cells in PFC and T cells, specifically the GR receptor promoter region alongside genes in the immune response, transcription and response to stimulus [91]. These findings suggest that peripheral GR methylation or cell specific (example T cells) methylation changes could be a potential biomarker for assessing early stress-induced HPA dysfunction. Genome-wide methylation studies show that childhood maltreatment leaves a systemic, genomewide mark by altering the methylation status of key genes in regulatory pathways such as intra and extra cellular signalling [77, 79, 80, 92, 93]. Although most work to date has focused on the stress response, it may be interesting to consider whether prolonged immune dysfunction that often persists after early stress is secondary to epigenetic changes in immunoregulatory genes as reported by Smith and colleagues in PTSD [81] or if it results indirectly from epigenetic changes in stress-regulatory genes.

\section{Conclusions}

Research to date highlights the remarkable susceptibility of the genome, and particularly of genes involved in stress and emotion regulation, to environmental alterations early in the lifespan. Many of these changes persisted into adulthood, and epigenetic mechanisms have been shown to contribute to the long-lasting nature of ELS and its contribution to an individual's disease risk and susceptibility to neuropsychiatric conditions across the lifespan.

\section{Abbreviations \\ 5-HTT: 5-hyrodxytryptamine transporter (serotonin transporter); ACTH: adrenocorticotrophic hormone; AVP: arginine vasopressin; BDNF: brain-derived neurotrophic factor; CA1: cornu ammonis 1; CpG: cytosine phosphate guanine; $\mathrm{CRH}$ : corticotrophin-releasing hormone; DNMT: DNA methyl transferase; ELS: early life stress; GAD1: glutamate decarboxylase 1; GR: glucocorticoid receptor; HDAC: histone deacetylase; HPA: hypothalamic-pituitary-adrenal axis; MD: maternal deprivation; MS: maternal separation; PCDH: protocadherin; PFC: prefrontal cortex; PND: postnatal day; PVN: para ventricular nucleus.}

\section{Competing interests}

The authors declare that they have no competing interests.

\section{Authors' contributions}

All authors meet the 3 authorship criteria of the International Committee of Medical Journal Editors. MCJ contributed to design, acquisition of data, analysis and interpretation of results along with drafting and revising the article. CM contributed to the design, interpretation of the data and revising for critically important intellectual content. ELH contributed to design, acquisition of data, analysis and interpretation and drafting the article. BTB contributed to conception and design, interpretation of the results and critically reviewing for intellectual content. All authors gave approval of the final version to be submitted.

\section{Acknowledgements}

The presented work is partly supported by the National Health and Medical Research Council Australia (APP1003788 to BTB). The funders had no role in study design, data collection and analysis, decision to publish or preparation of the manuscript.

\section{Author details}

1Discipline of Psychiatry, School of Medicine, University of Adelaide, Adelaide, SA 5005, Australia. ${ }^{2}$ School of HealthCare Science, Manchester Metropolitan University, Manchester, UK. ${ }^{3}$ School of Medicine and Dentistry, James Cook University, Townsville City, Australia.

Received: 18 September 2015 Accepted: 8 November 2015 Published online: 14 November 2015

\section{References}

1. Green JG, McLaughlin KA, Berglund PA, Gruber MJ, Sampson NA, Zaslavsky AM, et al. Childhood adversities and adult psychiatric disorders in the national comorbidity survey replication I: associations with first onset of DSM-IV disorders. Arch Gen Psychiatry. 2010;67(2):113-23.

2. Kessler RC, McLaughlin KA, Green JG, Gruber MJ, Sampson NA, Zaslavsky AM, et al. Childhood adversities and adult psychopathology in the WHO World Mental Health Surveys. Br J Psychiatry. 2010;197(5):378-85.

3. Bernet $\mathrm{CZ}$, Stein MB. Relationship of childhood maltreatment to the onset and course of major depression in adulthood. Depress Anxiety. 1999;9(4):169-74.

4. Varese F, Smeets F, Drukker M, Lieverse R, Lataster T, Viechtbauer W, et al. Childhood adversities increase the risk of psychosis: a meta-analysis of patient-control, prospective- and cross-sectional cohort studies. Schizophr Bull. 2012;38(4):661-71.

5. Scott KM, Von Korff M, Angermeyer MC, Benjet C, Bruffaerts R, de Girolamo $\mathrm{G}$, et al. Association of childhood adversities and early-onset mental disorders with adult-onset chronic physical conditions. Arch Gen Psychiatry. 2011;68(8):838-44

6. Scott KM, Von Korff M, Alonso J, Angermeyer MC, Benjet C, Bruffaerts R, et al. Childhood adversity, early-onset depressive/anxiety disorders, and adult-onset asthma. Psychosom Med. 2008;70(9):1035-43.

7. Gershon A, Sudheimer K, Tirouvanziam R, Williams LM, O'Hara R. The long-term impact of early adversity on late-life psychiatric disorders. Curr Psychiatry Rep. 2013;15(4):013-0352.

8. Kaplow JB, Widom CS. Age of onset of child maltreatment predicts long-term mental health outcomes. J Abnorm Psychol. 2007;116(1):176-87.

9. Schoedl AF, Costa MC, Mari JJ, Mello MF, Tyrka AR, Carpenter LL, et al. The clinical correlates of reported childhood sexual abuse: an association between age at trauma onset and severity of depression and PTSD in adults. J Child Sex Abus. 2010;19(2):156-70.

10. Evans GW, Schamberg MA. Childhood poverty, chronic stress, and adult working memory. Proc Natl Acad Sci. 2009;30:2009.

11. Felitti VJ, Anda RF, Nordenberg D, Williamson DF, Spitz AM, Edwards V, et al. Relationship of childhood abuse and household dysfunction to many of the leading causes of death in adults. The Adverse Childhood Experiences (ACE) Study. Am J Prev Med. 1998;14(4):245-58.

12. Wise LA, Zierler S, Krieger N, Harlow BL. Adult onset of major depressive disorder in relation to early life violent victimisation: a casecontrol study. Lancet. 2001;358(9285):881-7.

13. Gershon A, Minor K, Hayward C. Gender, victimization, and psychiatric outcomes. Psychol Med. 2008;38(10):1377-91.

14. Caspi A, Sugden K, Moffitt TE, Taylor A, Craig IW, Harrington H, et al. Influence of life stress on depression: moderation by a polymorphism in the 5-HTT gene. Science. 2003;301(5631):386-9.

15. Buchmann AF, Hellweg R, Rietschel M, Treutlein J, Witt SH, Zimmermann US, et al. BDNF Val 66 Met and 5-HTTLPR genotype moderate the impact of early psychosocial adversity on plasma brainderived neurotrophic factor and depressive symptoms: a prospective study. Eur Neuropsychopharmacol. 2013;23(8):902-9.

16. Binder EB, Bradley RG, Liu W, Epstein MP, Deveau TC, Mercer KB, et al. Association of FKBP5 polymorphisms and childhood abuse with risk of posttraumatic stress disorder symptoms in adults. JAMA. 2008;299(11):1291-305.

17. Heim C, Newport DJ, Mletzko T, Miller AH, Nemeroff CB. The link between childhood trauma and depression: insights from HPA axis studies in humans. Psychoneuroendocrinology. 2008;33(6):693-710. 
18. Danese A, Pariante CM, Caspi A, Taylor A, Poulton R. Childhood maltreatment predicts adult inflammation in a life-course study. Proc Natl Acad Sci U S A. 2007;104(4):1319-24.

19. McGowan P, Sasaki A, D'Alessio AC, Dymov S, Labonte B, Szyf M et al. Epigenetic regulation of the glucocorticoid receptor in human brain associates with childhood abuse. Nat Neurosci. 2009;12(3):342-8.

20. Weaver IC, Cervoni N, Champagne FA, D'Alessio AC, Sharma S, Seckl JR, et al. Epigenetic programming by maternal behavior. Nat Neurosci. 2004;7(8):847-54.

21. Franklin TB, Russig H, Weiss IC, Graff J, Linder N, Michalon A, et al. Epigenetic transmission of the impact of early stress across generations. Biol Psychiatry. 2010;68(5):408-15.

22. McGowan PO, Szyf M. The epigenetics of social adversity in early life: implications for mental health outcomes. Neurobiol Dis. 2010;39(1):66-72.

23. Murgatroyd C, Patchev A, Wu Y, Micale V, Bockmuhl Y, Fischer D, et al. Dynamic DNA methylation programs persistent adverse effects of early-life stress. Nat Neurosci. 2009;12(12):1559-66. doi:10.038/nn.2436. Epub 009 Nov 8.

24. Holsboer F. The corticosteroid receptor hypothesis of depression. Neuropsychopharmacology. 2000;23(5):477-501.

25. Meynen G, Unmehopa UA, van Heerikhuize JJ, Hofman MA, Swaab DF, Hoogendijk WJ. Increased arginine vasopressin mRNA expression in the human hypothalamus in depression: A preliminary report. Biol Psychiatry. 2006;60(8):892-5.

26. Raadsheer FC, Hoogendijk WJ, Stam FC, Tilders FJ, Swaab DF. Increased numbers of corticotropin-releasing hormone expressing neurons in the hypothalamic paraventricular nucleus of depressed patients. Neuroendocrinology. 1994;60(4):436-44.

27. Murgatroyd C, Spengler D. Epigenetics of early child development. Front Psychiatry. 2011;2:16

28. Bennett AJ, Lesch KP, Heils A, Long JC, Lorenz JG, Shoaf SE, et al. Early experience and serotonin transporter gene variation interact to influence primate CNS function. Mol Psychiatry. 2002;7(1):118-22.

29. Ansorge MS, Zhou M, Lira A, Hen R, Gingrich JA. Early-life blockade of the 5-HT transporter alters emotional behavior in adult mice. Science. 2004; 306(5697):879-81.

30. Gatt JM, Nemeroff CB, Dobson-Stone C, Paul RH, Bryant RA, Schofield PR, et al. Interactions between BDNF Val66Met polymorphism and early life stress predict brain and arousal pathways to syndromal depression and anxiety. Mol Psychiatry. 2009;14(7):681-95.

31. Cirulli F, Francia N, Berry A, Aloe L, Alleva E, Suomi SJ. Early life stress as a risk factor for mental health: role of neurotrophins from rodents to nonhuman primates. Neurosci Biobehav Rev. 2009;33(4):573-85.

32. Karege F, Perret G, Bondolfi G, Schwald M, Bertschy G, Aubry JM. Decreased serum brain-derived neurotrophic factor levels in major depressed patients. Psychiatry Res. 2002;109(2):143-8.

33. Black IB. Trophic regulation of synaptic plasticity. J Neurobiol. 1999;41(1):108-18

34. White KJ, Walline CC, Barker EL. Serotonin transporters: implications for antidepressant drug development. AAPS J. 2005;7(2):E421-33.

35. Lesch KP, Bengel D, Heils A, Sabol SZ, Greenberg BD, Petri S, et al. Association of anxiety-related traits with a polymorphism in the serotonin transporter gene regulatory region. Science. 1996;274(5292):1527-31

36. Egan MF, Kojima M, Callicott JH, Goldberg TE, Kolachana BS, Bertolino A, et al. The BDNF val66met polymorphism affects activity-dependent secretion of BDNF and human memory and hippocampal function. Cell. 2003;112(2):257-69.

37. van der Doelen RH, Calabrese F, Guidotti G, Geenen B, Riva MA, Kozicz T, et al. Early life stress and serotonin transporter gene variation interact to affect the transcription of the glucocorticoid and mineralocorticoid receptors, and the co-chaperone FKBP5, in the adult rat brain. Front Behav Neurosci. 2014;8:355

38. Osterlund MK, Hurd YL. Estrogen receptors in the human forebrain and the relation to neuropsychiatric disorders. Prog Neurobiol. 2001;64(3):251-67.

39. Champagne FA, Weaver IC, Diorio J, Sharma S, Meaney MJ. Natural variations in maternal care are associated with estrogen receptor alpha expression and estrogen sensitivity in the medial preoptic area. Endocrinology. 2003;144(11):4720-4. Epub 2003 Jul 24.

40. Pinheiro M, Ferraz-de-Paula V, Ribeiro A, Sakai M, Bernardi M, Palermo-Neto J. Long-term maternal separation differentially alters serum corticosterone levels and blood neutrophil activity in A/J and C57BL/6 mouse offspring. Neuroimmunomodulation. 2011;18(3):184-90. Epub 2011 Feb 9.

41. Roceri M, Hendriks W, Racagni G, Ellenbroek BA, Riva MA. Early maternal deprivation reduces the expression of BDNF and NMDA receptor subunits in rat hippocampus. Mol Psychiatry. 2002;7(6):609-16.
42. George ED, Bordner KA, Elwafi HM, Simen AA. Maternal separation with early weaning: a novel mouse model of early life neglect. BMC Neurosci. 2010;11:123

43. Weaver ICG, D'Alessio AC, Brown SE, Hellstrom IC, Dymov S, Sharma S, et al. The transcription factor nerve growth factor-inducible protein a mediates epigenetic programming: altering epigenetic marks by immediate-early genes. J Neurosci. 2007;27(7):1756-68.

44. Daniels WMU, Fairbairn L, Tilburg G, McEvoy C, Zigmond M, Russell V, et al. Maternal separation alters nerve growth factor and corticosterone levels but not the DNA methylation status of the exon 1(7) glucocorticoid receptor promoter region. Metab Brain Dis. 2009;24(4):615-27.

45. Kember RL, Dempster EL, Lee TH, Schalkwyk LC, Mill J, Fernandes C. Maternal separation is associated with strain-specific responses to stress and epigenetic alterations to $\mathrm{Nr} 3 \mathrm{Cl}, \mathrm{Avp}$, and $\mathrm{Nr} 4 \mathrm{a} 1$ in mouse. Brain Behav. 2012;2(4):455-67.

46. McGowan P, Suderman M, Sasaki A, Huang T, Hallett M, Meaney MJ, et al. Broad epigenetic signature of maternal care in the brain of adult rats. PLoS One. 2011;6(2):e14739.

47. Chen J, Evans A, Liu Y, Honda M, Saavedra J, Aguilera G. Maternal deprivation in rats is associated with corticotrophin-releasing hormone $(\mathrm{CRH})$ promoter hypomethylation and enhances $\mathrm{CRH}$ transcriptional responses to stress in adulthood. J Neuroendocrinol. 2012;24(7):1055-64.

48. Wang A, Nie W, Li H, Hou Y, Yu Z, Fan Q, et al. Epigenetic upregulation of corticotrophin-releasing hormone mediates postnatal maternal separationinduced memory deficiency. PLoS One. 2014;9(4):e94394.

49. Rishi V, Bhattacharya P, Chatterjee R, Rozenberg J, Zhao J, Glass K, et al. CpG methylation of half-CRE sequences creates C/EBPalpha binding sites that activate some tissue-specific genes. Proc Natl Acad Sci U S A. 2010;107(47):20311-6.

50. Zhang X, Odom DT, Koo SH, Conkright MD, Canettieri G, Best J, et al. Genome-wide analysis of CAMP-response element binding protein occupancy, phosphorylation, and target gene activation in human tissues. Proc Natl Acad Sci U S A. 2005;102(12):4459-64.

51. Murgatroyd C, Spengler D. Polycomb binding precedes early-life stress responsive DNA methylation at the Avp enhancer. PLoS One. 2014;9(3):e90277.

52. Roceri M, Cirulli F, Pressina C, Peretto P, Racagni G, Riva MA. Postnatal repeated maternal deprivation produces age-dependent changes of brainderived neurotrophic factor expression in selected rat brain regions. Biol Psychiatry. 2004;55(7):708-14.

53. Roth TL, Lubin FD, Funk A, Sweatt JD. Lasting epigenetic influence of earlylife adversity on the BDNF gene. Biol Psychiatry. 2009;65(9):760-9. doi:10. 1016/j.biopsych.2008.11.028. Epub 9 Jan 15.

54. Bai M, Zhu X, Zhang Y, Zhang S, Zhang L, Xue L, et al. Abnormal hippocampal BDNF and miR-16 expression is associated with depression-like behaviors induced by stress during early life. PLoS One. 2012;7(10):e46921.

55. Kinnally EL, Tarara E, Mason W, Mendoza S, Abel K, Lyons L, et al. Serotonin transporter expression is predicted by early life stress and is associated with disinhibited behavior in infant rhesus macaques. Genes Brain Behav. 2010;9(1):45-52

56. Lee J-H, Kim B-T, Kim HJ, Kim JG, Ryu V, Kang D-W, et al. Depressive behaviors and decreased expression of serotonin reuptake transporter in rats that experienced neonatal maternal separation. Neurosci Res. 2007:58(1):32-9.

57. Kinnally EL, Capitanio JP, Leibel R, Deng L, LeDuc C, Haghighi F, et al. Epigenetic regulation of serotonin transporter expression and behavior in infant rhesus macaques. Genes Brain Behav. 2010;9(6):575-82.

58. Kinnally EL, Feinberg C, Kim D, Ferguson K, Leibel R, Coplan JD, et al. DNA methylation as a risk factor in the effects of early life stress. Brain Behav Immun. 2011;25(8):1548-53

59. Champagne FA, Weaver ICG, Diorio J, Dymov S, Szyf M, Meaney MJ. Maternal care associated with methylation of the estrogen receptor-alpha1b promoter and estrogen receptor-alpha expression in the medial preoptic area of female offspring. Endocrinology. 2006;147(6):2909.

60. Volk DW, Austin MC, Pierri JN, Sampson AR, Lewis DA. Decreased glutamic acid decarboxylase 67 messenger RNA expression in a subset of prefrontal cortical gamma-aminobutyric acid neurons in subjects with schizophrenia. Arch Gen Psychiatry. 2000;57(3):237-45.

61. Heckers S, Stone D, Walsh J, Shick J, Koul P, Benes FM. Differential hippocampa expression of glutamic acid decarboxylase 65 and 67 messenger RNA in bipolar disorder and schizophrenia. Arch Gen Psychiatry. 2002;59(6):521-9.

62. Kundakovic M, Chen $\mathrm{Y}$, Costa $\mathrm{E}$, Grayson D. DNA methyltransferase inhibitors coordinately induce expression of the human reelin and glutamic acid decarboxylase 67 genes. Mol Pharmacol. 2007;71(3):644-53. 
63. Costa E, Dong E, Grayson DR, Ruzicka WB, Simonini MV, Veldic M, et al. Epigenetic targets in GABAergic neurons to treat schizophrenia. Adv Pharmacol. 2006;54:95-117.

64. Fatemi SH, Earle JA, McMenomy T. Reduction in Reelin immunoreactivity in hippocampus of subjects with schizophrenia, bipolar disorder and major depression. Mol Psychiatry. 2000;5(6):654-63.

65. Guidotti A, Sharma R, Uzunov D, Costa E, Auta J, Davis JM, et al. Decrease in Reelin and glutamic acid decarboxylase67 (GAD67) expression in schizophrenia and bipolar disorder: a postmortem brain study. Arch Gen Psychiatry. 2000;57(11):1061-9.

66. Zhang T-Y, Hellstrom IC, Bagot R, Wen X, Diorio J, Meaney MJ. Maternal care and DNA methylation of a glutamic acid decarboxylase 1 promoter in rat hippocampus. J Neurosci. 2010;30(39):13130-7. doi:10.1523/JNEUROSCI.1039-10.2010.

67. Qin L, Tu W, Sun X, Zhang J, Chen Y, Zhao H. Retardation of neurobehavioral development and reelin down-regulation regulated by further DNA methylation in the hippocampus of the rat pups are associated with maternal deprivation. Behav Brain Res. 2011;217(1):142-7.

68. Aas M, Djurovic S, Athanasiu L, Steen NE, Agartz I, Lorentzen S, et al. Serotonin transporter gene polymorphism, childhood trauma, and cognition in patients with psychotic disorders. Schizophr Bull. 2012;38(1):15-22.

69. Suderman M, McGowan PO, Sasaki A, Huang TC, Hallett MT, Meaney MJ, et al. Conserved epigenetic sensitivity to early life experience in the rat and human hippocampus. Proc Natl Acad Sci U S A. 2012;109 Suppl 2:17266-72.

70. Perroud N, Paoloni-Giacobino A, Prada P, Olie E, Salzmann A, Nicastro R, et al. Increased methylation of glucocorticoid receptor gene (NR3C1) in adults with a history of childhood maltreatment: a link with the severity and type of trauma. Transl Psychiatry. 2011;1:e59.

71. Tyrka AR, Price LH, Marsit C, Walters OC, Carpenter LL. Childhood adversity and epigenetic modulation of the leukocyte glucocorticoid receptor: preliminary findings in healthy adults. PLoS One. 2012;7(1):e30148.

72. Murgatroyd C, Quinn J, Sharp H, Pickles A, Hill J. Effects of prenatal and postnatal depression, and maternal stroking, at the glucocorticoid receptor gene. Transl Psychiatry. 2015. In press.

73. Philibert RA, Sandhu H, Hollenbeck N, Gunter T, Adams W, Madan A. The relationship of 5HTT (SLC6A4) methylation and genotype on mRNA expression and liability to major depression and alcohol dependence in subjects from the lowa Adoption Studies. Am J Med Genet B Neuropsychiatr Genet. 2008;147B(5):543-9.

74. Beach SR, Brody GH, Todorov AA, Gunter TD, Philibert RA. Methylation at SLC6A4 is linked to family history of child abuse: an examination of the lowa adoptee sample. Am J Med Genet B Neuropsychiatr Genet. 2010;153B(2):710-3.

75. Beach SR, Brody GH, Todorov AA, Gunter TD, Philibert RA. Methylation at $5 \mathrm{HTT}$ mediates the impact of child sex abuse on women's antisocial behavior: an examination of the lowa adoptee sample. Psychosom Med. 2011;73(1):83-7.

76. Kang HJ, Kim JM, Stewart R, Kim SY, Bae KY, Kim SW, et al. Association of SLC6A4 methylation with early adversity, characteristics and outcomes in depression. Prog Neuropsychopharmacol Biol Psychiatry. 2013;44:23-8.

77. Naumova OY, Lee M, Koposov R, Szyf M, Dozier M, Grigorenko EL. Differential patterns of whole-genome DNA methylation in institutionalized children and children raised by their biological parents. Dev Psychopathol. 2012;24(1):143-55.

78. Labonte B, Yerko V, Gross J, Mechawar N, Meaney MJ, Szyf M, et al. Differential glucocorticoid receptor exon $1(B), 1(C)$, and $1(H)$ expression and methylation in suicide completers with a history of childhood abuse. Biol Psychiatry. 2012;72(1):41-8.

79. Borghol N, Suderman M, McArdle W, Racine A, Hallett M, Pembrey M, et al. Associations with early-life socio-economic position in adult DNA methylation. Int J Epidemiol. 2012;41(1):62-74.

80. Mehta D, Klengel T, Conneely KN, Smith AK, Altmann A, Pace TW, et al. Childhood maltreatment is associated with distinct genomic and epigenetic profiles in posttraumatic stress disorder. Proc Natl Acad Sci U S A. 2013; 110(20):8302-7.

81. Smith AK, Conneely KN, Kilaru V, Mercer KB, Weiss TE, Bradley B, et al. Differential immune system DNA methylation and cytokine regulation in post-traumatic stress disorder. Am J Med Genet B Neuropsychiatr Genet. 2011;156B(6):700-8.
82. Champagne FA, Meaney MJ. Transgenerational effects of social environment on variations in maternal care and behavioral response to novelty. Behav Neurosci. 2007;121(6):1353-63.

83. Levine A, Worrell TR, Zimnisky R, Schmauss C. Early life stress triggers sustained changes in histone deacetylase expression and histone $\mathrm{H} 4$ modifications that alter responsiveness to adolescent antidepressant treatment. Neurobiol Dis. 2012;45(1):488-98.

84. Massart R, Suderman M, Provencal N, Yi C, Bennett AJ, Suomi S, et al. Hydroxymethylation and DNA methylation profiles in the prefrontal cortex of the non-human primate rhesus macaque and the impact of maternal deprivation on hydroxymethylation. Neuroscience. 2014;268:139-48.

85. Maciag D, Simpson KL, Coppinger D, Lu Y, Wang Y, Lin RCS, et al. Neonatal antidepressant exposure has lasting effects on behavior and serotonin circuitry. Neuropsychopharmacology. 2006;31(1):47-57.

86. Ikegame T, Bundo M, Murata Y, Kasai K, Kato T, Iwamoto K. DNA methylation of the BDNF gene and its relevance to psychiatric disorders. J Hum Genet. 2013;58(7):434-8.

87. Kundakovic M, Gudsnuk K, Herbstman JB, Tang D, Perera FP, Champagne FA. DNA methylation of BDNF as a biomarker of early-life adversity. Proc Natl Acad Sci U S A. 2014;112(22):6807-13. doi:10.1073/pnas.1408355111.

88. Martinowich K, Lu B. Interaction between BDNF and serotonin: role in mood disorders. Neuropsychopharmacology. 2008;33(1):73-83.

89. Madhav TR, Pei Q, Zetterstrom TS. Serotonergic cells of the rat raphe nuclei express $m R N A$ of tyrosine kinase $B$ (trkB), the high-affinity receptor for brain derived neurotrophic factor (BDNF). Brain Res Mol Brain Res. 2001;93(1):56-63.

90. Solum DT, Handa RJ. Estrogen regulates the development of brain-derived neurotrophic factor mRNA and protein in the rat hippocampus. J Neurosci. 2002;22(7):2650-9.

91. Provencal N, Suderman MJ, Guillemin C, Massart R, Ruggiero A, Wang D, et al. The signature of maternal rearing in the methylome in rhesus macaque prefrontal cortex and T cells. J Neurosci. 2012;32(44):15626-42.

92. Khulan B, Manning JR, Dunbar DR, Seckl JR, Raikkonen K, Eriksson JG, et al. Epigenomic profiling of men exposed to early-life stress reveals DNA methylation differences in association with current mental state. Transl Psychiatry. 2014;4:e448.

93. Labonte B, Suderman M, Maussion G, Navaro L, Yerko V, Mahar I, et al. Genome-wide epigenetic regulation by early-life trauma. Arch Gen Psychiatry. 2012;69(7):722-31.

94. Levine S. Infantile experience and resistance to physiological stress. Science. 1957;126(3270):405.

95. Laban O, Markovic B, Dimitruevic M, Jankovic B. Maternal deprivation and early weaning modulate experimental allergic encephalomyelitis in the rat. Brain Behav Immun. 1995;9(1):9-19.

96. Plotsky P, Meaney M. Early, postnatal experience alters hypothalamic corticotropin-releasing factor (CRF) mRNA, median eminence CRF content and stress-induced release in adult rats. Brain Res Mol Brain Res. 1993;18(3):195-200.

97. Liu D, Diorio J, Tannenbaum B, Caldji C, Francis D, Freedman A, et al. Maternal care, hippocampal glucocorticoid receptors, and hypothalamicpituitary-adrenal responses to stress. Science. 1997;277(5332):1659.

98. McGowan PO, Sasaki A, Huang TC, Unterberger A, Suderman M, Ernst C, et al. Promoter-wide hypermethylation of the ribosomal RNA gene promoter in the suicide brain. PLoS One. 2008;3(5):e2085.

\section{Submit your next manuscript to BioMed Central and take full advantage of:}

- Convenient online submission

- Thorough peer review

- No space constraints or color figure charges

- Immediate publication on acceptance

- Inclusion in PubMed, CAS, Scopus and Google Scholar

- Research which is freely available for redistribution 